\title{
The stoichiometry of the Escherichia coli Hfq protein bound to RNA
}

\author{
TAYLOR B. UPDEGROVE, ${ }^{1,2}$ JOHN J. CORREIA, ${ }^{3}$ YANFENG CHEN, ${ }^{2}$ CHARLES TERRY, ${ }^{1,2}$ \\ and ROGER M. WARTELL ${ }^{1,2}$ \\ ${ }^{1}$ School of Biology, Georgia Institute of Technology, Atlanta, Georgia 30332, USA \\ ${ }^{2}$ Parker H. Petit Institute for Bioscience and Bioengineering, Georgia Institute of Technology, Atlanta, Georgia 30332, USA \\ ${ }^{3}$ Department of Biochemistry, University of Mississippi Medical Center, Jackson, Mississippi 39216, USA
}

\begin{abstract}
The Escherichia coli RNA binding protein $\mathrm{Hfq}$ is involved in many aspects of post-transcriptional gene expression. Tight binding of $\mathrm{Hfq}$ to polyadenylate sequences at the $3^{\prime}$ end of mRNAs influences exonucleolytic degradation, while $\mathrm{Hfq}$ binding to small noncoding RNAs (sRNA) and their targeted mRNAs facilitate their hybridization which in turn effects translation. Hfq binding to an A-rich tract in the 5' leader region of the rpoS mRNA and to the sRNA DsrA have been shown to be important for DsrA enhanced translation initiation of this mRNA. The complexes of Hfq-A 18 and $\mathrm{Hfq}-\mathrm{DsrA}$ provide models for understanding how $\mathrm{Hfq}$ interacts with these two RNA sequence/structure motifs. Different methods have reported different values for the stoichiometry of $\mathrm{Hfq}-\mathrm{A}_{18}$ and $\mathrm{Hfq}-\mathrm{DsrA}$. In this work, mass spectrometry and analytical ultracentrifugation provide direct evidence that the strong binding mode of the $\mathrm{Hfq}$ hexamer $\left(\mathrm{Hfq}_{6}\right)$ for $\mathrm{A}_{18}$ and domain II of DsrA (Dsr $\left.A_{D I I}\right)$ involve 1:1 complexes. This stoichiometry was also supported by fluorescence anisotropy and a competition gel mobility shift experiment using wild-type and truncated $\mathrm{Hfq}$. More limited studies of $\mathrm{Hfq}$ binding to DsrA as well as to the sRNAs RprA, OxyS, and an 18-nt segment of OxyS were also consistent with 1:1 stoichiometry. Mass spectrometry of crosslinked samples of $\mathrm{Hfq}_{6}, A_{18}$, and Dsr $A_{D I I}$ exhibit intensity corresponding to a ternary 1:1:1 complex; however, the small intensity of this peak and fluorescence anisotropy experiments did not provide evidence that this ternary complex is stable in solution.
\end{abstract}

Keywords: Hfq; DsrA; RprA; OxyS; MALDI-TOF

\section{INTRODUCTION}

The Hfq protein of Escherichia coli is a RNA binding protein and a key factor in post-transcriptional gene regulation (Valentin-Hansen et al. 2004; Majdalani et al. 2005; Brennan and Link 2007; Waters and Storz 2009). E. coli Hfq and its bacterial homologs have been implicated in various facets of bacterial metabolism, including stressinduced sRNA regulation of mRNA translation as well as mRNA stability. In addition to its well-documented interaction with RNA, Hfq has been found associated with DNA (Takada et al. 1997; Azam et al. 2000; Updegrove et al. 2010) as well as a number of proteins (Butland et al. 2005). The nature of Hfq's interactions with DNA and many of the proteins are not well understood; however,

Reprint requests to: Roger M. Wartell, School of Biology, Georgia Institute of Technology, Atlanta, Georgia 30332, USA; e-mail: roger. wartell@biology.gatech.edu; fax: (404) 894-0519.

Article published online ahead of print. Article and publication date are at http://www.rnajournal.org/cgi/doi/10.1261/rna.2452111. there is increasing recognition that they may reflect additional functions of Hfq (Le Derout et al. 2010).

Considerable attention has been focused on the role of Hfq in gene regulation by noncoding small RNAs (sRNAs). A number of sRNAs, such as OxyS, SgrS, DsrA, RprA, Spot42, and Qrr1-4, require Hfq to facilitate their regulation of mRNA translation (Sledjeski et al. 2001; Majdalani et al. 2002; Moller et al. 2002a,b; Zhang et al. 2002; Lenz et al. 2004; Kawamoto et al. 2006). In vitro studies suggest that Hfq's role is to enhance the association rate and/or stability of a sRNA to its mRNA target site near the start codon (Geissmann and Touati 2004; Kawamoto et al. 2006; Soper and Woodson 2008; Updegrove et al. 2008). The formation of a sRNA-mRNA hybrid can inhibit or enhance ribosome accessibility to mRNA, thus providing either negative or positive regulation of translation (Majdalani et al. 2005; Waters and Storz 2009). Hfq's presence in the cell enhances sRNA stability and its capacity for functional interaction with mRNA targets. Hfq has also been shown to influence mRNA stability in vivo by enhancing sRNA-mRNA 
interaction or by binding mRNA directly (Tsui et al. 1997; Vytvytska et al. 1998; Masse et al. 2003; Morita et al. 2005).

In addition to its interactions with the translational initiation regions of mRNAs, $\mathrm{Hfq}$ also influences the stability of some mRNAs through its interaction with their $3^{\prime}$ ends. It has been estimated that $>90 \%$ of the $E$. coli transcriptome possess post-transcriptionally added poly(A) tails (Mohanty and Kushner 2006). Studies show that Hfq stimulates the addition of poly (A) tails to the $3^{\prime}$ end of some mRNAs by poly(A) polymerase I (PAP) (Le Derout et al. 2003; Mohanty et al. 2004; Folichon et al. 2005). In vivo, inactivation of the $h f q$ gene reduces the length of poly(A) tails synthesized at the $3^{\prime}$ end of the $r p s O$ mRNA by PAP, and in vitro, the addition of $\mathrm{Hfq}$ increases the processivity of PAP on $r p s O \mathrm{mRNA}$. The addition of $\operatorname{poly}(\mathrm{A})$ tails has been shown to enhance mRNA decay in eubacteria (Steege 2000). Studies also indicate that $\mathrm{Hfq}$ binding to poly $(\mathrm{A})$ tails can prevent mRNAs from binding to enzymes involved in RNA degradation (Folichon et al. 2003, 2005; Mohanty et al. 2004). Understanding the role of Hfq in the degradation of mRNAs requires understanding how $\mathrm{Hfq}$ binds to the $3^{\prime}$ ends of mRNAs with poly(A) tails, as well as with PAP and possibly other RNA processing enzymes.

Initial studies on Hfq binding to RNA homopolymers and oligomers demonstrated that $\mathrm{Hfq}$ has a strong affinity for poly (A) and $A_{n}$ oligomers with $n>15$ (Carmichael et al. 1975; de Haseth and Uhlenbeck 1980b). Studies on the binding of mutant $\mathrm{Hfq}$ to $\mathrm{A}_{\mathrm{n}}$ oligomers indicated that the distal surface of the $\mathrm{Hfq}$ hexamer $\left(\mathrm{Hfq}_{6}\right)$ interacts with poly(A) sequences (Mikulecky et al. 2004; Sun and Wartell 2006). A binding model proposed to accommodate information on the complex (Brennan and Link 2007), and a recent crystal structure of $E$. coli $\mathrm{Hfq}$ and $\mathrm{A}_{15}$ imply that the $\mathrm{Hfq}_{6}$ forms a 1:1 complex with $\mathrm{A}_{\mathrm{n}}$ oligomers. However, experimental studies employing several methodologies suggested different stoichiometries for Hfq and oligoriboadenylates. Isothermal titration calorimetry suggested one $\mathrm{Hfq}_{6}$ bound to two $\mathrm{A}_{18}$ (Mikulecky et al. 2004), while fluorescence anisotropy, fluorescence quenching and a gel shift assay supported a model in which two $\mathrm{Hfq}_{6}$ was bound to one $A_{18}$ (Sun and Wartell 2006).

DsrA is an 87-nucleotide (nt) sRNA that acts as a positive regulator for the translation of the stationary phase sigma factor RpoS. Hfq facilitates DsrA binding to the leader region of the rpoS mRNA and releases an inhibitory stemloop that sequesters the Shine-Delgarno (SD) sequence (Cunning et al. 1998). Hfq binds both DsrA and rpoS mRNA with similar affinities (Soper and Woodson 2008; Updegrove et al. 2008). Studies have explored the number of $\mathrm{Hfq}$ molecules binding to each RNA participant. Gel shift measurements yielded data supporting a 2:1 ( $\left.\mathrm{Hfq}_{6}: \mathrm{RNA}\right)$ binding model for a 138-nt segment of rpoS mRNA, DsrA (Lease and Woodson 2004), and DsrA ${ }_{\text {DII }}$ (Sun and Wartell 2006), while isothermal titration calorimetry indicated a 1:1 complex for $\mathrm{Hfq}_{6}$ binding to DsrA and a segment of $r p o S$ mRNA (Mikulecky et al. 2004).

The ability of $\mathrm{Hfq}$ to stimulate sRNA-mRNA duplex formation has been observed under both in vitro and in vivo conditions. How Hfq recognizes and binds each of the RNAs and facilitates their pairing remains obscure. Evidence that Hfq can alter secondary and/or tertiary structure of some sRNAs and mRNAs lends support to the notion that Hfq acts as a chaperone and modulates the sRNA and/ or mRNA structure, making one or the other RNA more amendable for heteroduplex formation. Another role ascribed to $\mathrm{Hfq}$ is an ability to bind and hold two pairing RNA molecules simultaneously, thus bringing them in close proximity and driving the reaction to favor sRNA-mRNA duplex formation. However, we note that the ability of $\mathrm{Hfq}$ to separately bind two complementary RNAs is not always sufficient to promote RNA pairing (Arluison et al. 2007). Exactly how $\mathrm{Hfq}$ brings together two independent RNA molecules depends on the number of Hfq hexamers required to bind each RNA molecule and the number and type of RNAs that can simultaneously bind each $\mathrm{Hfq}$ hexamer. The stoichiometry of $\mathrm{Hfq}_{6}$ binding to RNA is clearly pertinent to understanding the mechanism of how Hfq promotes ribo-regulation.

The focus of the current work was to determine the stoichiometry of the strong binding complexes of Hfq with $\mathrm{A}_{18}$ and $\mathrm{Dsr}_{\mathrm{DII}}$. The oligoriboadenylate $\mathrm{A}_{18}$ mimics the size and sequence of poly(A) tails at the $3^{\prime}$ end of mRNAs, and results on how this oligonucleotide interacts with $\mathrm{Hfq}$ may be of functional significance in terms of Hfq's role and mechanism in facilitating polyadenylation by poly $(\mathrm{A})$ polymerase. DsrA ${ }_{\text {DII }}$, a 38-nt portion of DsrA (nucleotides 2360 ), competes with DsrA for binding to Hfq (Brescia et al. 2003). It contains a stem-loop and U-rich segment of DsrA that binds Hfq. Mass spectrometry, fluorescence anisotropy, and analytical ultracentrifugation provide evidence supporting a 1:1 stoichiometry for $\mathrm{Hfq}_{6}$ and oligo $\mathrm{A}_{18}$ as well as for $\mathrm{Hfq}_{6}$ and $\mathrm{DsrA}_{\mathrm{DII}}$. A competition electrophoretic gel mobility shift assay also supports 1:1 complexes for $\mathrm{Hfq}_{6}$ binding to $\mathrm{A}_{18}$ as well as to full-length DsrA, RprA, and OxyS.

\section{RESULTS}

\section{MALDI-TOF mass spectroscopy indicates $\mathrm{Hfq}_{6}$ forms a 1:1 complex with DsrA $A_{\text {DII }}, A_{18}$, and OxyS-18}

MALDI-TOF (matrix-assisted laser desorption ionizationtime of flight) mass spectrometry was first used to examine the molecular mass of E. coli $\mathrm{Hfq}$ alone and then as a complex with $A_{18}$. These experiments were done in the absence of cross-linking as well as after EDC cross-linking of the $\mathrm{Hfq}-\mathrm{A}_{18}$ complex prior to mass spectrometric analysis. The MALDI-TOF spectrum of Hfq shown in Figure 1a was carried out with EDC cross-linking and reveals discrete ions 

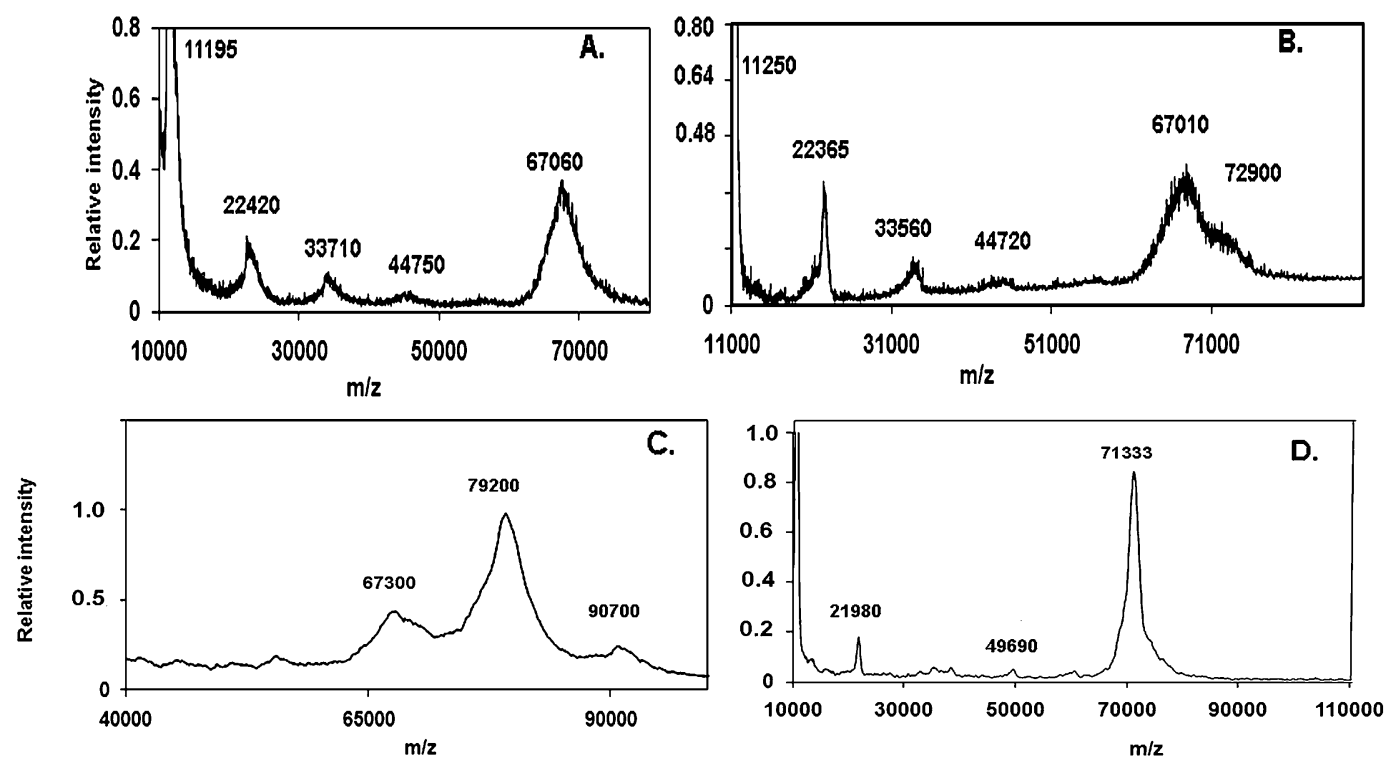

FIGURE 1. MALDI-TOF $\mathrm{m} / \mathrm{z}$ spectra of $2 \mu \mathrm{M} \mathrm{Hfq}_{6}(A), 2 \mu \mathrm{M} \mathrm{Hfq} \mathrm{q}_{6}$ and $0.7 \mu \mathrm{M} \mathrm{A}_{18}(B), 8 \mu \mathrm{M} \mathrm{Hfq}$ and $4 \mu \mathrm{M}$ DsrA domain II $(C)$, and $4 \mu \mathrm{M}$ $\mathrm{Hfq}_{6}$ and $2 \mu \mathrm{M}$ OxyS-18 $(D)$. All samples were prepared in the $0.2 \mathrm{M} \mathrm{Na}^{+}$solvent and matrix solution as described in Materials and Methods.

with $\mathrm{m} / \mathrm{z}$ ratios corresponding to the $\mathrm{Hfq}$ monomer and multimers up to the hexamer $(67,060 \mathrm{Da}$; theoretical mass, $66,998 \mathrm{Da})$. This observation is in agreement with a previous study (Moller et al. 2002a) and illustrates that Hfq can stably exist as multimers up to the hexamer in the laser desorption ionization process. We note that macromolecules are generally expected to be singly charged ions in MALDI-TOF experiments (Karas et al. 2000).

The addition of $0.7 \mu \mathrm{M} \mathrm{A}_{18}$ to $2 \mu \mathrm{M} \mathrm{Hfq}_{6}$ resulted in the formation of an additional peak corresponding to a molecular mass of 72,900 Da (Fig. 1b). Since the theoretical mass of $A_{18}$ is $5,840 \mathrm{Da}$, this new peak is very close to an expected complex with a $1: 1$ ratio of $\mathrm{Hfq}_{6}$ to $\mathrm{A}_{18}$ (theoretical mass, $72,839 \mathrm{Da}$ ). No peaks were observed at the molecular mass corresponding to $2: 1$ or $1: 2$ ratios of $\mathrm{Hfq}_{6}$ to $\mathrm{A}_{18}$. Similar results were also obtained when $0.07 \mu \mathrm{M} \mathrm{A} A_{18}$ and $0.2 \mu \mathrm{M} \mathrm{Hfq}_{6}$ were employed with and without EDC crosslinking (data not shown). The addition of EDC increased the relative signal intensities of the $\mathrm{Hfq}_{6}$ and $\mathrm{Hfq}_{6} \bullet \mathrm{A}_{18} \mathrm{com}$ plex over the Hfq subunit multimers, consistent with suppression of hexamer dissociation.

The $\mathrm{Hfa}_{6}-\mathrm{DsrA}_{\mathrm{DII}}$ complex required a more robust cross-linking agent to withstand the conditions imposed by the MALDI-TOF experiment. Formaldehyde proved to be an efficient cross-linker and allowed detection of the $\mathrm{Hf}_{6} \mathrm{f}_{-}$ $D_{\text {Dr }} A_{\text {DII }}$ complex. Figure 1c shows a spectrum resulting from a mixture of $8 \mu \mathrm{M} \mathrm{Hfq} \mathrm{q}_{6}$ with $4 \mu \mathrm{M} \mathrm{DsrA}_{\mathrm{DII}}$. A pronounced peak occurs at a $\mathrm{m} / \mathrm{z}$ ratio of 79,200 flanked by less pronounced peaks of 67,300 and 90,700 . Since the theoretical molecular weight of $\mathrm{DsrA}_{\mathrm{DII}}$ is $12,031 \mathrm{Da}$, the large middle peak is consistent with one $\mathrm{Hfq}_{6}$ bound to one $\mathrm{DsrA}_{\mathrm{DII}}$. The smaller and larger molecular weight peaks are consistent with $\mathrm{Hfq}_{6}$ and one $\mathrm{Hfq}_{6}$ bound to two DsrA $\mathrm{DII}_{\text {II }}$ molecules, re- spectively. DsrA $A_{\text {DII }}$ has been shown to form two bands at low $\mu \mathrm{M}$ concentrations in a polyacrylamide gel environment (Sun and Wartell 2006). When $2 \mu \mathrm{M} \mathrm{Hfq} \mathrm{q}_{6}$ was added to 1 $\mu \mathrm{M}$ DsrA $_{\mathrm{DII}}$, only the 79,000 and $67,000 \mathrm{~m} / \mathrm{z}$ peaks were observed (data not shown). Unfortunately a MALDI-TOF experiment with full-length DsrA and Hfq gave weak or negligible signals barely above background at the $\mathrm{m} / \mathrm{z}$ ratio expected for $\mathrm{Hfq}_{6} \cdot$ DsrA or higher masses. The larger negative charge intrinsic to the full-length DsrA molecule appears to compromise a study of this complex by this method.

OxyS is a 109-nt sRNA that was shown to bind Hfq in vitro and in vivo and acts as a negative regulator for the translation of the rpoS mRNA. A 18-nt portion of OxyS sRNA that spans nucleotides $64-81$ is thought to be critical for Hfq binding based on the observation that an oligonucleotide complementary to this region strongly inhibits Hfq from binding to the full-length OxyS molecule (Zhang et al. 2002). MALDITOF was used to assess the stoichiometry of Hfq binding to this segment of OxyS. When $4 \mu \mathrm{M}$ of $\mathrm{Hfq}_{6}$ was added to 2 $\mu \mathrm{M}$ OxyS-18 and formaldehyde is used as the cross-linking agent, only one extremely large peak was observed at an $\mathrm{m} / \mathrm{z}$ ratio of 71333 (Fig. 1d). With the theoretical molecular weight of OxyS-18 being 5769.6 Da, the large peak in Figure $1 \mathrm{~d}$ is in good agreement with one Hfq hexamer bound to one OxyS-18. No peak was detected at an $\mathrm{m} / \mathrm{z}$ ratio corresponding to either $1: 2$ or $2: 1 \mathrm{Hfq}_{6}$ to OxyS-18 stoichiometry.

\section{Analytical ultracentrifugation analysis of $\mathrm{Hfq} \cdot \mathrm{A}_{18}$ complex in solution}

Analytical ultracentrifugation analysis was employed to determine the stoichiometry of the Hfq- $\mathrm{A}_{18}$ complex in aqueous solution. Sedimentation velocity of $\mathrm{Hfq}$ alone in 
$0.5 \mathrm{M} \mathrm{NaCl}$ and $20 \mathrm{mM}$ Tris (8.2) indicated a single major species with a sedimentation coefficient $(s)$ of $s=3.42 \mathrm{sec}$ $<3.41,3.44>$ and no more than $2 \%$ of a higher molecular weight aggregate with $s=5.56 \mathrm{~S}$. Figure 2 a shows the results of a sedimentation velocity experiment of $\mathrm{Hfq}$ analyzed using the $c(s)$ method (Schuck et al. 2002). The sedimentation coefficient distribution was independent of loading concentrations from 3.2-12.1 $\mu \mathrm{M}$ Hfq in moles hexamer. Direct boundary fitting of the sedimentation velocity data using SedAnal (Stafford and Sherwood 2004) indicated a molecular weight for the $3.42 \mathrm{~S}$ species of $64,815 \mathrm{Da}$ $<59,733,70,301>$. This value is slightly lower than the expected value of $66,998 \mathrm{Da}$ and is consistent with the hexamer being the dominant $\mathrm{Hfq}$ species at these concentrations. The slightly lower than expected value can be explained by uncertainty in the partial specific volume employed or the influence of the minor aggregate on the fit. (Traces of sediment velocity run and model fitting using SedAnal are given in Supplemental Fig. S1.)

Figure $2 \mathrm{~b}$ shows the normalized $\mathrm{g}(s)$ distribution of concurrently run sedimentation velocity experiments which examined $6.9 \mu \mathrm{M} \mathrm{Hfq}{ }_{6}$ alone, $6.9 \mu \mathrm{M} \mathrm{Hfq} 6$ with $4.4 \mu \mathrm{M}$ FAM-A $_{18}$, and $6.9 \mu \mathrm{M} \mathrm{Hfq}$ with $8.3 \mu \mathrm{M}$ FAM-A 18 . FAM$\mathrm{A}_{18}$ binding increased the sedimentation coefficient of $\mathrm{Hfq}_{6}$ from $3.3 \mathrm{~S}$ to $3.9 \mathrm{~S}$. At the concentration ratio of [FAM- $\left.\mathrm{A}_{18}\right] /$ [Hfq $\mathrm{H}_{6}$ of 1.2 , a trailing boundary of excess FAM-A $\mathrm{A}_{18}$ is observed. Free FAM- $\mathrm{A}_{18}$ has a sedimentation coefficient of $1.355 \mathrm{~S}<1.345,1.364>$ with no evidence of concentration dependence or additional species (data not shown). Using

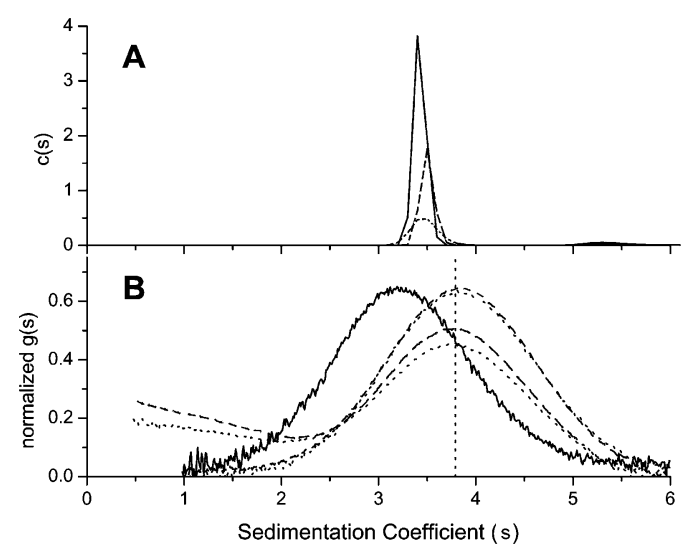

FIGURE 2. (A) Sedimentation coefficient distribution $c(s)$ determined by program Sedfit for three different $\mathrm{Hfq}_{6}$ concentrations, 3.2, 5.7, and $12 \mu \mathrm{M}$ shown as dotted, dashed, and solid lines, respectively. The average integrated value for these data is $3.51 \pm 0.03 \mathrm{~S}$. (B) Sedimentation coefficient distribution displayed as normalized $\mathrm{g}(s)$ for $\mathrm{Hfq}_{6}$ at $6.9 \mu \mathrm{M}$ alone as solid line (average integrated value for Hfq data is $3.42 \pm 0.04 \mathrm{~S}$ ), and with $4.4 \mu \mathrm{M}$ and $8.3 \mu \mathrm{M}$ FAM-A $_{18}$ added. Upper pair of overlapping dashed and dotted lines show the 6.9:4.4 mixture evaluated by absorbance at $274 \mathrm{~nm}$ and $495 \mathrm{~nm}$, respectively. Lower pair of dashed and dotted lines display the 6.9:8.3 mixture evaluated at the same two wavelengths. Lack of alignment of $\mathrm{c}(s)$ and $\mathrm{g}(s)$ peaks for $\mathrm{Hfq}_{6}$ alone $(3.51 \mathrm{~S}$ vs. $3.42 \mathrm{~S})$ is attributed to minor components affecting the main $\mathrm{c}(s)$ peak. the SedAnal software, a good fit to the Hfq- $\mathrm{A}_{18}$ data was obtained with a model that assumed Hfq hexamer binds $\mathrm{A}_{18}$ with a 1:1 stoichiometry. The best Sedanal fit (constraining $\mathrm{S}$ for $\mathrm{Hfq}$ and FAM-A $\mathrm{A}_{18}$ ) returned a $\mathrm{K}$ of $1.71 \times$ $10^{7} \mathrm{M}^{-1}<0.85, \mathrm{UB}>$. The unbounded upper limit means all larger values of $\mathrm{K}$ are indistinguishable in the leastsquares sense. A subsequent run with a new protein sample returned a larger $\mathrm{K} \sim 10^{10} \mathrm{M}^{-1}$ with $95 \%$ confidence limits of $<7.5 \times 10^{7}, \mathrm{UB}>$. Thus the data is consistent with a tight $1: 1 \mathrm{Hfq}-\mathrm{A}_{18}$ complex with an affinity in excess of $10^{7} \mathrm{M}^{-1}$.

Sedimentation equilibrium runs of 2 , 4 , and $8 \mu \mathrm{M} \mathrm{Hfq} 6$ alone and mixed with 1:1 molar ratios of FAM- $\mathrm{A}_{18}$ confirmed that the stoichiometry of the $\mathrm{Hfq}_{6} \cdot \mathrm{FAM}-\mathrm{A}_{18} \mathrm{com}-$ plex in solution is not 2:1, but 1:1. The evaluated molecular weight of $\mathrm{Hfq}$ alone was $61.475 \mathrm{kDa}<58.8,64.2>(\mathrm{rms}=$ 0.00596) (Supplemental Fig. S2), similar to the value obtained from sedimentation velocity analysis. Analysis of the sedimentation equilibrium data of the Hfq•FAM- $\mathrm{A}_{18}$ mixtures, monitored at the FAM-A $\mathrm{A}_{18}$ absorbance peak of $495 \mathrm{~nm}$, yielded a molecular weight of $68.93 \mathrm{kDa}<67.4$, $70.4>(\mathrm{rms}=0.00724)$ (Supplemental Fig. S2). This clearly does not correspond to a complex consisting of $2 \mathrm{Hfq}_{6}$ molecules and one $A_{18}$ molecule but is consistent with a 1:1 complex.

\section{Gel mobility shift study of wild-type Hfq and Hfq-65 binding to $A_{18}$ and other RNAs}

Previous gel mobility experiments in which $\mathrm{A}_{18}$ or other RNAs were titrated with $\mathrm{Hfq}$ at concentrations above apparent $\mathrm{K}_{\mathrm{d}}$ values indicated $2: 1 \mathrm{Hfq}_{6}$ to RNA stoichiometry (Lease and Woodson 2004; Sun and Wartell 2006; Updegrove et al. 2008). Since these previous results conflict with the above findings, we examined the stoichiometry of $\mathrm{Hfq} \bullet \mathrm{A}_{18}$ complexes in the gel environment using a different approach that relies on a qualitative comparison rather than quantative analysis of band intensities. The $\mathrm{Hfq} \bullet \mathrm{A}_{18}$ complexes that formed in the presence of wild-type (wt) Hfq and Hfq-65 were determined. Hfq-65 is a truncated variant of wt $\mathrm{Hfq}$ consisting of 65 residues from the $\mathrm{N}$-terminal end. This truncated Hfq was previously shown to bind DsrA two- to threefold less well than wt Hfq, and to $\mathrm{A}_{27}$ with an affinity similar to wt Hfq (Vecerek et al. 2008). Lane 3 of Figure $3 a$ shows the gel-shift of the Hfq-65• $\mathrm{A}_{18}$ complex in a $6 \%$ PAG. The Hfq- $65 \bullet \mathrm{A}_{18}$ complex migrates with a slower mobility than the wt $\mathrm{Hfq} \bullet \mathrm{A}_{18}$ complex (lane 2) in spite of its reduced size. A plausible explanation of this phenomenon is the increased positive charge of Hfq-65 compared to wt Hfq. Hfq-65 has four less negatively charged residues (Asp 97, Glu 99, Glu 100, and Glu 102) and one less positively charged residue (Arg 66) than each wt $\mathrm{Hfq}$ subunit. When equimolar amounts of wt $\mathrm{Hfq}$ and Hfq- 65 were mixed with $\mathrm{A}_{18}$ for $5 \mathrm{~min}$ and run into the gel, two bands were observed corresponding to wt $\mathrm{Hfq} \bullet \mathrm{A}_{18}$ 

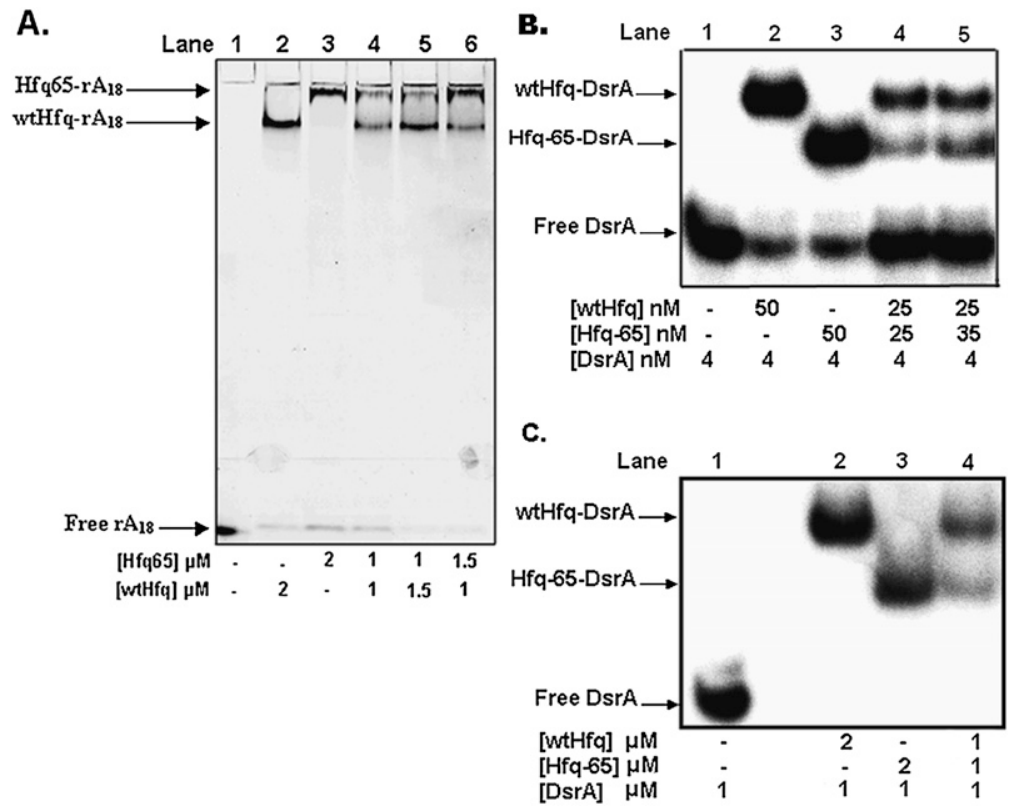

FIGURE 3. DsrA and $A_{18}$ bind both wt Hfq and Hfq-65 in a $1: 1$ stoichiometry. Varying concentrations in moles hexamer/L of wt $\mathrm{Hfq}$ and Hfq- 65 were added to $1 \mu \mathrm{M}$ FAM- $\mathrm{A}_{18}(A)$, $4 \mathrm{nM}^{32} \mathrm{P}$-DsrA $(B)$, and $1 \mu \mathrm{M}{ }^{32} \mathrm{P}$-DsrA $(C)$. Similar results were obtained when ${ }^{32} \mathrm{P}$ end-labeled RprA and OxyS sRNAs were added to both wt Hfq and Hfq-65.

and Hfq- $65 \cdot \mathrm{A}_{18}$ (Fig. 3a, lane 4). This result is consistent with a 1:1 stoichiometry for complexes of $\mathrm{Hfq}_{6}$ and $\mathrm{A}_{18}$. If the stoichiometry of the $\mathrm{Hfq} \bullet \mathrm{A}_{18}$ complexes were two $\mathrm{Hfq}_{6}$ and one $A_{18}$, a band of intermediate mobility would be expected in lane 4. Changing the ratio of wt $\mathrm{Hfq}$ and $\mathrm{Hfq}-65$ concentrations altered the intensity of the two bands in direct proportion, but no additional band is observed (Fig. $3 a$, lanes 5,6).

When $4 \mathrm{nM}{ }^{32} \mathrm{P}$-labeled DsrA was added to $50 \mathrm{nM}$ of either wt Hfq or Hfq-65 (moles hexamer), most of the RNA was shifted to a slower moving complex. Under these conditions, the DsrA $\bullet \mathrm{Hfq}-65$ complex migrates faster than the DsrA $\bullet w t$ Hfq complex (Fig. 3b, lanes 2,3). Since DsrA has considerably more negative charge than $A_{18}$, it will likely dominate the charge differences between wt $\mathrm{Hfq}$ and Hfq-65. The size difference between wt Hfq and Hfq-65, rather than their intrinsic charge difference, appears to be the governing factor in the migration of these Hfq.DsrA complexes. When $25 \mathrm{nM}$ wt $\mathrm{Hfq}$ and $25 \mathrm{nM}$ Hfq-65 (moles hexamer) were added to $4 \mathrm{nM}$ DsrA, only two apparent slow migrating bands were evident; one corresponding to the DsrA•wt Hfq complex and the other corresponding to the DsrA•Hfq-65 complex (Fig. 3b, lane 4). Similarly, when $1 \mu \mathrm{M}$ each of wt Hfq and Hfq-65 was added to $1 \mu \mathrm{M}$ DsrA, only two slow migrating bands were observed (Fig. 3c, lane 4). The outcome was the same when $25 \mathrm{nM}$ wt Hfq and $25 \mathrm{nM}$ Hfq-65 was added to $4 \mathrm{nM}$ ${ }^{32}$ P-labeled OxyS or RprA (data not shown). The results are consistent with a $1: 1$ stoichiometry for $\mathrm{Hfq}_{6}$ binding to these RNAs.

\author{
Hfq binding to $A_{18}$ or Dsr $A_{D I I}$ \\ monitored by fluorescence \\ anisotropy.
}

Another experimental approach that suggested two $\mathrm{Hfq}_{6}$ bound $\mathrm{A}_{18}$ was fluorescence anisotropy (Sun and Wartell 2006). A model in which two $\mathrm{Hfq}_{6}$ sequentially bound $\mathrm{A}_{18}$ gave a better fit to fluorescence anisotropy data than a model that assumed a 1:1 complex. We have reexamined and extended these measurements and the analyses in light of the above results. Figure $4 \mathrm{a}$ shows that the 2:1 binding model (solid line) does give the best fit to the titration of Hfq to $2 \mathrm{nM}$ of FAM-labeled $\mathrm{A}_{18}$. The dotted line is the nonlinear least-squares fit of the 1:1 model (Equation 1 in the Materials and Methods), with $K_{d}$ a variable parameter and the other parameters $\left(A_{f}, A_{b},[\mathrm{R}]_{\mathrm{T}}\right.$, $\left.[\mathrm{P}]_{\mathrm{T}}\right)$ determined from the experimental data. The $A_{b}$ value of 0.166 was determined from the horizontal asymptote to the anisotropy values of the four highest $\mathrm{Hfq}_{6}$ concentrations used in the experiment. If, however, one allows $A_{b}$ to be somewhat flexible and assume a value of 0.185 , the fit of the 1:1 model approaches that of the 2:1 model (dashed line). Considering that the 2:1 model has more variable parameters with which to fit the data, the difference between the two models no longer persuasively favors the 2:1 model. Both models indicate $K_{d}$ values in the range of $5-10 \mathrm{nM}$.

To further examine the stoichiometry of $\mathrm{Hfq}_{6}$ binding to $\mathrm{A}_{18}$ using this experimental approach, the titration of $\mathrm{A}_{18}$ with $\mathrm{Hfq}$ was carried out at concentrations well above the $\mathrm{K}_{\mathrm{d}}\left(5 \mu \mathrm{M} \mathrm{A}_{18}\right)$ where stoichiometric binding is expected. Figure $4 \mathrm{~b}$ shows that the anisotropy change of $\mathrm{A}_{18}$ saturates at a ratio of $\mathrm{Hfq}_{6}$ and $\mathrm{A}_{18}$ consistent with a 1:1 stoichiometry. A similar experiment conducted with $2 \mu \mathrm{M} \mathrm{DsrA}_{\mathrm{DII}}$ also showed a break in the plot at a 1:1 molar ratio of $\mathrm{Hfq}_{6}$ and $D_{s r A}$ DII (Fig. 4c). The $\mathrm{K}_{\mathrm{d}}$ of $\mathrm{Hfq}_{6}$ binding to DsrA $\mathrm{A}_{\mathrm{DII}}$ under the conditions of the experiment $(0.1 \mathrm{M} \mathrm{NaCl}+20$ $\mathrm{mM}$ Tris) was $\sim 4 \mathrm{nM}$ (Supplemental Fig. S3).

\section{$\mathrm{Hfq}$ interaction with both $\mathrm{A}_{\mathbf{1 8}}$ and DsrA $\mathrm{A}_{\mathrm{DII}}$}

Polyacrylamide gel mobility shift experiments have previously demonstrated that $\mathrm{Hfq}$ can form a complex with a poly(A) sequence and DsrA (Brescia et al. 2003). The observation of a "super shifted" gel band consisting of the above three components indicates a ternary complex but does not exclude the possibility that more than one Hfq hexamer is needed to form this complex. MALDI-TOF mass spectrometry was employed to examine if a mass could be 

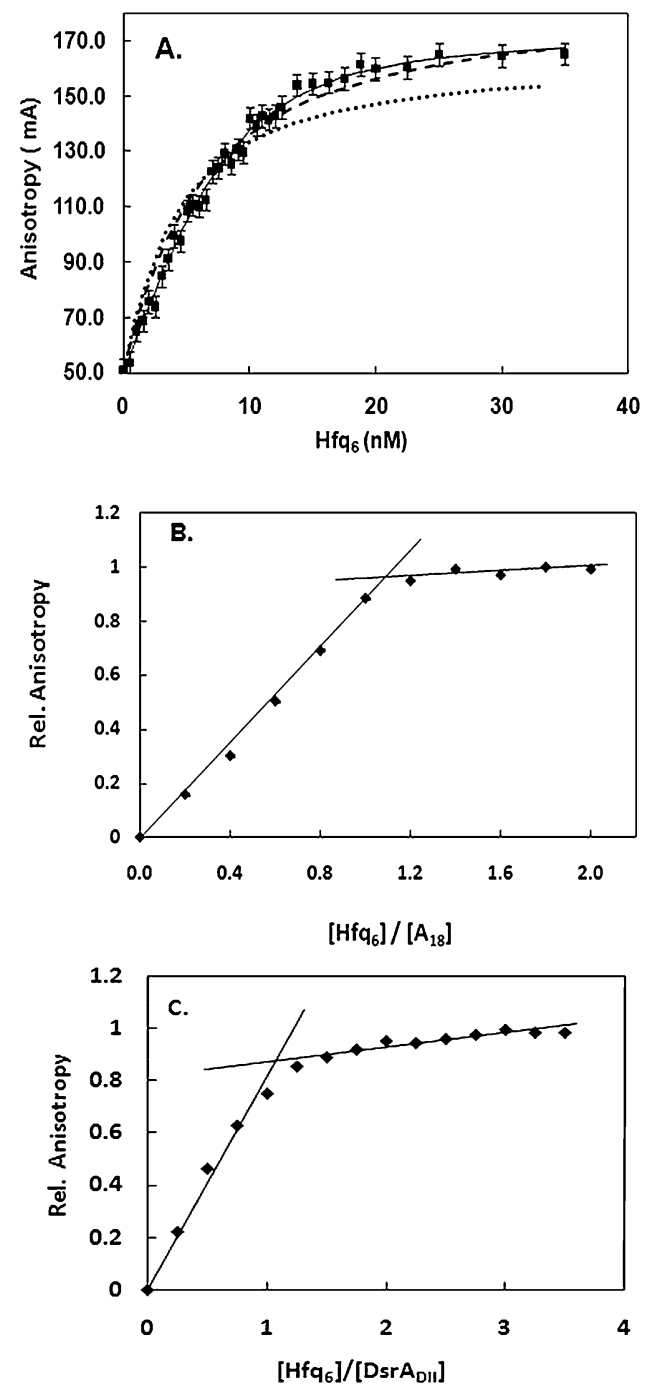

FIGURE 4. Fluorescence anisotropy titration of FAM- $\mathrm{A}_{18}$ with Hfq. (A) Comparison of experimental data with $2 \mathrm{nM}$ FAM- $\mathrm{A}_{18}$ (squares) to best fit of 2:1 model (solid line), 1:1 model with $\mathrm{K}_{\mathrm{d}}$ variable (circles), and 1:1 model with variable $\mathrm{K}_{\mathrm{d}}$ and $A_{b}$ (dotted line). Parameters for: $2: 1$ model; $\mathrm{K}_{1}=10.1 \mathrm{nM}, \mathrm{K}_{2}=5 \mathrm{nM}, A_{b 1}=0.148$, $A_{b 2}=0.172$. For 1:1 models; $\mathrm{K}_{1}=4.4 \mathrm{nM}, A_{b}=0.166$ for dotted line, $\mathrm{K}_{1}=5 \mathrm{nM}, \mathrm{A}_{\mathrm{b}}=0.185$ for dashed line. $(B)$ Experimental anisotropy measurements of $5 \mu \mathrm{M}$ FAM- $\mathrm{A}_{18}$ titrated with $\mathrm{Hfq}_{6}$. $(C)$ Experimen-

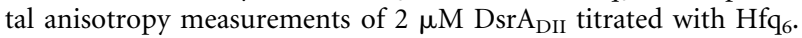

detected consistent with a complex formed by $\mathrm{Hfq}_{6}, \mathrm{DsrA}_{\mathrm{DII}}$, and $\mathrm{A}_{18}$. We mixed $10 \mu \mathrm{M} \mathrm{Hfq}_{6}$ with $5 \mu \mathrm{M} \mathrm{DsrA}_{\mathrm{DII}}$ and $5 \mu \mathrm{M} \mathrm{A} \mathrm{A}_{18}$ for $15 \mathrm{~min}$, which was treated with formaldehyde as described in Materials and Methods. Figure 5 shows the MALDI-TOF spectrum of this sample. Peaks were observed corresponding to molecular masses very similar to $\mathrm{Hfq}_{6}$ $(66,650 \mathrm{Da}$; theoretical mass, $66,998 \mathrm{Da}), \mathrm{Hfq}_{6} \mathrm{~A}_{18}(72,400$ $\mathrm{Da}$; theoretical mass, $72,839 \mathrm{Da})$, and $\mathrm{Hfq}_{6} \cdot \mathrm{DsrA}_{\text {DII }}(78,230$ $\mathrm{Da}$; theoretical mass, 79,029 Da). A small but reproducible peak was observed in the region corresponding to a mass of $84,355 \mathrm{Da}$, consistent with the combined mass of one $\mathrm{Hfq}_{6}$, one $\mathrm{A}_{18}$, and one DsrA $\mathrm{D}_{\mathrm{DII}}$ (theoretical mass, $84,869 \mathrm{Da}$ ). We note that the lower observed masses compared to theoretical masses (by 350-700 Da) appears to be due to external calibration error.

The small peak corresponding to a mass of $55,530 \mathrm{Da}$ is consistent with five subunits of $\mathrm{Hfq}$ (theoretical mass, $55,832 \mathrm{Da}$ ). Small nearby peaks were reproducibly observed and may be related to four or five subunits of Hfq with $A_{18}$, $D_{\text {srA }} A_{\text {DII }}$, or both. The intensities of peaks corresponding to the unbound forms of four and five Hfq subunits were slightly higher (relative to the Hfq monomer peak) in the presence of both $\mathrm{DsrA}_{\mathrm{DII}}$ and $\mathrm{A}_{18}(\sim 3 \%)$ compared to when only one RNA was present $(\sim 2 \%)$. Not surprisingly, the $\mathrm{Hfq} \bullet \mathrm{A}_{18}$ and $\mathrm{Hfq} \bullet D s r \mathrm{~A}_{\mathrm{DII}}$ peaks were smaller by about 2.5-fold when both DsrA $A_{D I I}$ and $A_{18}$ were present compared with spectra of Hfq and only one RNA. The small peak at 89,515 is consistent with one $\mathrm{Hfq}_{6}$ and a dimer of DsrA DII and is similar to the small peak observed with Hfq and DsrA $_{\text {DII }}$ (Fig. 1c).

The intensity in the region of the $84,355 \mathrm{Da}$ mass in Figure 5 is consistent with a $1: 1: 1 \mathrm{Hfq}_{6} \bullet \mathrm{A}_{18} \bullet \mathrm{DsrA}_{\text {DII }}$ ternary complex; however, this peak was considerably smaller than the peaks corresponding to $\mathrm{Hfq}_{6} \bullet \mathrm{A}_{18}$ or $\mathrm{Hfq}_{6} \bullet \mathrm{DsrA}_{\mathrm{DII}}$. This may reflect an intrinsic instability of this ternary complex or a limitation of the method in reporting complexes of $\mathrm{Hfq}_{6}$ with two RNAs.

To explore this question in solution, we examined the effect of adding DsrA $\mathrm{DII}_{\mathrm{DI}}$ on the fluorescence anisotropy of a preformed complex of $\mathrm{Hfq}_{6} \cdot \mathrm{FAM}-\mathrm{A}_{18}$. $\mathrm{Hfq}_{6}$ was added to $100 \mathrm{nM}$ FAM- $\mathrm{A}_{18}$ in a solvent of $0.1 \mathrm{M} \mathrm{NaCl}+20 \mathrm{mM}$ Tris (8.3), increasing the anisotropy from 0.037 to 0.080 , about $45 \%$ of the maximum anisotropy change induced by saturating $\mathrm{Hfq}_{6}$. Adding aliquots of $\mathrm{DsrA}_{\mathrm{DII}}$ to produce a final solution with $75 \mathrm{nM}$ FAM- $\mathrm{A}_{18}, 65 \mathrm{nM}$ DsrA $\mathrm{DII}_{\text {, }}$ and $63 \mathrm{nM}$ $\mathrm{Hfq}_{6}$ reduced the anisotropy by about $30 \%$ (Fig. 6). If a ternary $\mathrm{Hfq}_{6} \cdot \mathrm{A}_{18} \bullet \mathrm{DsrA}_{\mathrm{DII}}$ complex is stable relative to the 1:1 $\mathrm{Hf}_{\mathrm{f}_{6}} \bullet \mathrm{RNA}$ complexes, an increase rather than decrease in anisotropy is expected. This experiment was repeated using the complete DsrA, surmising its higher molecular weight and strong binding to $\mathrm{Hfq}_{6}$ may be required to

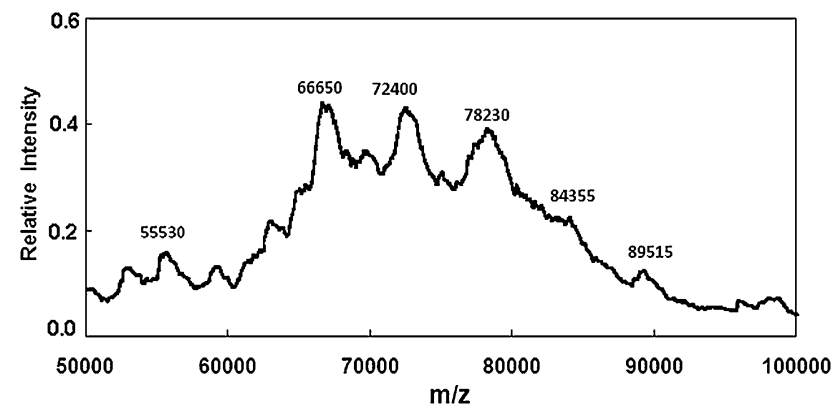

FIGURE 5. MALDI-TOF $\mathrm{m} / \mathrm{z}$ spectrum of $10 \mu \mathrm{M} \mathrm{Hfq} \mathrm{H}_{6}$ plus $5 \mu \mathrm{M}$ $D_{\text {DrA }}$ DII and $5 \mu \mathrm{M} \mathrm{A}_{18}$ prepared in the $0.2 \mathrm{M} \mathrm{Na}^{+}$solvent, cross-linked with formaldehyde, and mixed with matrix solution as described in Material and Methods. 


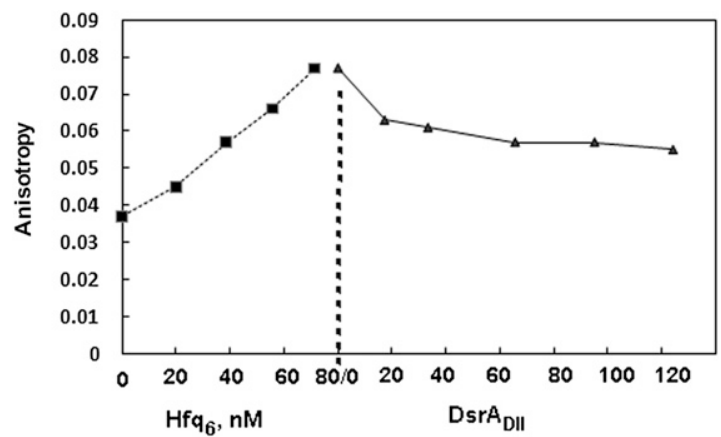

FIGURE 6. Fluorescence anisotropy experiment of FAM-A18 with Hfq and DsrA $A_{\text {DII }}$. Hfq was titrated to $100 \mathrm{nM} \mathrm{FAM-A_{18 }}$ to give 0.080 , $\sim 45 \%$ of the maximum anisotropy. Then aliquots of unlabeled DsrA $_{\text {DII }}$ were added to give the concentrations shown.

observe the expected anisotropy increase resulting from formation of a ternary complex. However the outcome was similar (data not shown). When Hfq and FAMDsrA $_{\text {DII }}$ were preformed and $A_{18}$ or polyA added to the solution, a similar decrease in anisotropy was observed (data not shown). The above results were surprising given the outcome of gel shift experiments (Brescia et al. 2003; Mikulecky et al. 2004; Updegrove et al. 2008) that clearly show complexes can form involving $\mathrm{Hfq}_{6}$, DsrA, and a poly A sequence. The apparently disparate implications of the two types of experiments may, however, be reconcilable as discussed below.

\section{DISCUSSION}

The results from mass spectrometry, analytical ultracentrifugation, fluorescence anisotropy, and competition gel mobility shift assay all point to a 1:1 stoichiometry for the $\mathrm{Hfq}_{6} \cdot \mathrm{A}_{18}$ and $\mathrm{Hfq}_{6} \bullet$ DsrA $\mathrm{A}_{\text {DII }}$ complexes. The more limited studies on Hfq binding to the RNAs DsrA, RprA, OxyS and OxyS-18 support a similar conclusion. These experiments were carried out with RNA concentrations from $4 \mathrm{nM}$ to $5 \mu \mathrm{M}$ in solvents with $0.1-0.5 \mathrm{M} \mathrm{Na}^{+}$. The 1:1 stoichiometry is the same value determined by isothermal titration calorimetry measurements of $\mathrm{Hfq}_{6}$ binding DsrA or a 140-nt rpoS mRNA segment (Mikulecky et al. 2004), but differs from the 2:1 ( $\mathrm{Hf}_{6}$ :RNA) stoichiometry inferred from gel shift assays of $\mathrm{Hfq}_{6}$ binding to DsrA, a 138-nt rpoS RNA (Lease and Woodson 2004), DsrA DII (Sun and Wartell 2006), and RprA (Updegrove et al. 2008), as well as the fluorescence anisotropy and fluorescence quenching study of $\mathrm{Hfa}_{6}$ binding to $\mathrm{A}_{18}$ (Sun and Wartell 2006). Since two methods used in the current work, mass spectrometry and sedimentation equilibrium, are robust model-independent approaches, our results raise the question why a 2:1 stoichiometry was inferred from previous investigations.

The results described by Figure 4a provide an explanation why a 2:1 stoichiometry was previously misinterpreted from the fluorescence anisotropy measurements of $\mathrm{Hfq}$ binding to $\mathrm{FAM}-\mathrm{A}_{18}$ at low nanomolar concentrations. The anisotropy of the fully bound FAM- $\mathrm{A}_{18}, A_{b}$, appears to have been previously underestimated. Increasing the experimentally derived value of $A_{b}$ by $\sim 11 \%$ produced a much better fit to the data using the 1:1 model. Assuming some flexibility in the $A_{b}$ value can be justified since there is uncertainty in the $\mathrm{Hfq}_{6}$ concentration required to saturate binding of FAM$\mathrm{A}_{18}$. With this adjustment to $A_{b}$, the difference between the predictions of the 2:1 model versus the 1:1 model no longer persuasively favors the $2: 1$ model.

The 2:1 stoichiometry inferred from the gel shift assay was suggested by equilibrium binding analyses of gel shift data obtained using 2-4 nM RNA that indicated a Hill coefficient above 2 , as well as from data obtained with 400 $\mathrm{nM}$ to $1.0 \mu \mathrm{M}$ of RNA, concentrations above the $\mathrm{K}_{\mathrm{d}}$ (Lease and Woodson 2004; Sun and Wartell 2006). Since similar outcomes came from different laboratories, it seems unlikely that differences in binding activity of Hfa preparations influenced this outcome. Also, the Hfq used in the current experiments, which yield a 1:1 stoichiometry, reproduced the outcome of the gel shift assay (data not shown). While a definitive argument cannot yet be made why the gel shift assay yielded a 2:1 stoichiometry, several factors that might complicate interpretation of gel shift data may provide an explanation.

The equilibrium established in the sample solution may be altered as the low ionic strength buffer $(0.5 \times$ TBE) exchanges with the loading buffer as the macromolecules enter the gel or during electrophoresis (Bloomfield et al. 2000). Although a low ionic strength solution may stabilize Hfq $\bullet$ RNA complexes, it has also been shown to produce well-ordered fibers of $\mathrm{Hfq}_{6}$ (Arluison et al. 2006). If $\mathrm{Hfq}_{6}$ aggregates in the gel environment it could alter the nature or amount of the Hfq $\bullet$ RNA complexes.

Factors governing the mass transport of Hfq $\bullet$ RNA complexes in a gel may also contribute to misleading interpretation of gel shift data, independent of the potential for $\mathrm{Hfq}_{6}$ aggregation. Using a phenomenological theory of gel electrophoresis, Cann (1989) simulated the gel patterns produced by several protein-DNA interactions employing association and dissociation rate constants representative of the interactions and experimentally derived transport parameters. The simulations validated the application of the gel shift method for determining binding constants and stoichiometry for strong interactions with association $\left(k_{a}\right)$ and dissociation $\left(\mathrm{k}_{\mathrm{d}}\right)$ rate constants of $\mathrm{k}_{\mathrm{a}}=3 \times 10^{9}$ $\mathrm{M}^{-1} \mathrm{sec}^{-1}, \mathrm{k}_{\mathrm{d}}=1.3 \times 10^{-4} \mathrm{sec}^{-1}$. However the simulation also showed that a significant amount of the initial proteinnucleic acid complex entering the gel can irreversibly dissociate during electrophoresis. When parameters mimicking an intermediate strength complex were used $\left(\mathrm{k}_{\mathrm{a}}=1.3 \times\right.$ $10^{6} \mathrm{M}^{-1} \mathrm{sec}^{-1}, \mathrm{k}_{\mathrm{d}}=1.3 \times 10^{-4} \mathrm{sec}^{-1}$ ) with $10 \mathrm{nM}$ each of protein and nucleic acid, $49 \%$ of the initial proteinnucleic acid complex irreversibly dissociated from this 
band during electrophoresis. The extent of irreversible dissociation of the initial protein-nucleic acid complexes clearly depends on the concentrations used and the parameters of the system. The importance of these considerations has been demonstrated for properly interpreting gel shift data on a repressor-DNA operator system (Kleinschmidt et al. 1991).

It is worth noting that in the above example although electrophoresis depleted the amount of material in the nucleic acid-protein band, the unbound nucleic acid band could still be used to calculate the equilibrium dissociation constant to good accuracy (Cann 1989). Thus gel shift data can be used to evaluate binding constants, even when the nucleic acid-protein bands do not accurately reflect the initial amount of these complexes. We note that interpretation of the competition gel shift experiment described in Figure 3 does not depend on a quantitative evaluation of band intensities. The absence of a band intermediate between the shifted bands corresponding to RNA bound to wt-Hfq or Hfq-65 is consistent with 1:1 complexes.

The third method that suggested a 2:1 stoichiometry for $\mathrm{Hfq}_{6} \bullet \mathrm{A}_{18}$ was fluorescence quenching of Hfq's tyrosines by $\mathrm{A}_{18}$. Quenching of $\mathrm{Hfq}$ fluorescence saturated when the amount of added $A_{18}$ reached a molar ratio of 0.5:1 $\left(\mathrm{A}_{18}\right.$ : $\mathrm{Hfq}_{6}$ ) (Sun and Wartell 2006). Controls indicated that the inner filter effect (Lakowicz 2006) due to the absorbance of $\mathrm{A}_{18}$ at the excitation wavelength was negligible. We are currently unable to reconcile the apparent 2:1 stoichiometry implied from this experiment with the 1:1 stoichiometry determined in the current work. It is possible that $A_{18}$ binding has a complex effect on the fluorescence of Hfq's three tyrosines such that a straightforward interpretation of the data is quantitatively flawed.

Several lines of evidence have shown that $\mathrm{Hfq}_{6}$ possesses two distinct RNA binding surfaces (Mikulecky et al. 2004). The proximal surface appears to be involved in Hfq binding to a single-stranded sequence with several uracils and/or adenines adjacent to one or more hairpins (Schumacher et al. 2002; Zhang et al. 2002; Geissmann and Touati 2004). The distal surface of $\mathrm{Hfq}_{6}$ binds to a repeated motif $(\mathrm{ARN})_{\mathrm{n}}, n \geq 4$ (with $\mathrm{R}$ a purine, $\mathrm{N}$ any nucleoside) (Link et al. 2009). The latter motif includes the poly(A) sequence at the $3^{\prime}$ ends of mRNAs, and segments found in the $5^{\prime}$ leader region of at least two mRNAs (Soper and Woodson 2008; Salim and Feig 2010). With two distinct binding surfaces, a single Hfq hexamer has the potential to bind a mRNA and sRNA simultaneously.

The MALDI-TOF results suggest the existence of a $\mathrm{Hfq}_{6} \bullet \mathrm{A}_{18} \bullet \mathrm{DsrA}_{\text {DII }}$ complex; however, the small size of the peak does not support the notion that a 1:1:1 complex is very stable. The fluorescence anisotropy experiment in Figure 6 also does not provide evidence for a stable ternary complex in solution. DsrA and $\mathrm{A}_{18}$ do not appear to bind Hfq independently under the conditions of the experiment. This appears to contradict the observation that polyA sequences can form a ternary complex with $\mathrm{Hfq}_{6}$ and DsrA in polyacrylamide gels. A possible explanation of these observations may be related to the low ionic strength solvent and cage effect of the gel environment. Studies by de Haseth and Uhlenbeck (1980a) as well as the more recent demonstration of Hfq fibers (Arluison et al. 2006) indicate that low ionic strength solutions promote $\mathrm{Hfq}$ aggregation. The gel environment may promote $\mathrm{Hfq}_{6}$ aggregation and enable ternary complexes that involve more than one $\mathrm{Hfq}_{6}$. These complexes may not form in the $0.1 \mathrm{M} \mathrm{Na}^{+}$solution employed in the anisotropy experiment.

A counter hypothesis that can explain why putative ternary complexes are not reported by fluorescence anisotropy is more difficult. If the dissociation lifetime of a ternary complex is shorter than its rotational correlation time $\left(\tau_{\mathrm{c}}\right)$ it could go undetected. For a 1:1:1 complex of DsrA, FAM$\mathrm{A}_{18}$, and $\mathrm{Hfq}_{6}, \tau_{\mathrm{c}}$ can be estimated to be $\sim 60 \mathrm{nsec}$ (Serdyuk et al. 2007). A dissociation lifetime this short is inconsistent with a stable ternary complex. The total anisotropy reflects the sum of each anisotropic species. Binding of DsrA $\mathrm{A}_{\mathrm{DI}}$ or DsrA to FAM-A $18 \cdot \mathrm{Hfq}_{6}$ is expected to slow the rotational correlation time and increase anisotropy. If binding also induces a conformational change that partially releases the FAM $-\mathrm{A}_{18}$, it may cancel the effect of the increased size on the rotational correlation time and in principle could reduce the anisotropy. In order to explain all of the results, this would also have to be true for $\mathrm{A}_{18}$ binding to $\operatorname{Dsr}_{\mathrm{DII}} \bullet \mathrm{Hfq}_{6}$. This seems a less likely explanation of the data than displacement of the bound RNA from $\mathrm{Hfq}_{6}$ by the other RNA.

Regardless of the uncertainty and a definitive explanation for the stoichiometry reported by the previous gel results and the nature of the polyA-Hfq-DsrA complex observed in gels, the major conclusion from this work, that $\mathrm{Hfq}_{6}$ has a 1:1 binding stoichiometry with RNA at concentration and ionic strength conditions mimicking a cell environment, addresses a question important to understanding how Hfq facilitates interactions between RNAs.

\section{MATERIALS AND METHODS}

\section{Purification and characterization of wt and mutant $\mathrm{Hfq}$}

The Impact-CN intein system (New England Biolabs) was used to purify $\mathrm{Hfq}$ proteins as previously described (Sun and Wartell 2006). The plasmids used to overexpress the Hfq proteins contained the E. coli $h f q$ gene inserted into SapI-SmaI-digested pTYB11 plasmid (pEcHfq) or mutant derivatives (see below). Protein purification was carried out according to the recommendation of the manufacturer using strain ER2566. Cell lysis was carried out using a French press. The cell lysate was centrifuged and the supernatant loaded onto a chitin column. The column was extensively washed with the lysis/wash buffer of $20 \mathrm{mM}$ Tris ( $\mathrm{pH} 8.3$ ) and $1 \mathrm{M} \mathrm{NaCl}$ prior to incubation of the column with this buffer plus $40 \mathrm{mM}$ dithiothreitol. The eluted protein was 
concentrated and buffer-exchanged to $0.5 \mathrm{M} \mathrm{NaCl}$ and $20 \mathrm{mM}$ Tris ( $\mathrm{pH}$ 8.3) using centrifugation filtration units.

To remove contaminating nucleic acids, Hfq preparations were subjected to a micrococcal nuclease treatment. Twenty-five microliters of $300 \mathrm{U} / \mathrm{mL}$ micrococal nuclease (Worthington Biochemical) was added to $1 \mathrm{~mL}$ of $0.3-0.4 \mathrm{OD}_{274 \mathrm{~nm}} \mathrm{Hfq}$ in $0.2 \mathrm{M}$ $\mathrm{NaCl}, 20 \mathrm{mM}$ Tris ( $\mathrm{pH} 8.5$ ), and $5 \mathrm{mM} \mathrm{CaCl}_{2}$ and incubated for $45 \mathrm{~min}$ at $37^{\circ} \mathrm{C}$. This nuclease has a strict dependence on $\mathrm{Ca}^{2+}$. Ten microliters of $0.5 \mathrm{M} \mathrm{Na}_{2}$ EDTA was added, and sample was washed and concentrated in $15 \mathrm{~mL}$ of $0.5 \mathrm{M} \mathrm{NaCl}$ and $20 \mathrm{mM}$ Tris (pH 8.3) using $30 \mathrm{kDa}$ MWCO Amicon Utrafiltration cell.

The mutant Hfq protein, Hfq-65, was produced for this study from the plasmid pHfq-65, which was generated from $\mathrm{pEcHfq}$ using the QuikChange Mutagenesis Kit from Stratagene (Sun and Wartell 2006). Oligonucleotides employed placed a stop codon at position 66 of the $h f q$ gene: $5^{\prime}$ - GCGATTTCTACTGTTGTC CCGTCTTAGCCGGTTTCTCATCACAG-3' and 5'-CTGTGATG AGAA ACCGGCTAAGACGGGAC AACAGTAGAAATCGC-3'. The plasmid construct was verified by DNA sequencing. The purification procedure for the mutant protein was similar to that used for wt Hfq. All proteins displayed expected molecular weights on a denaturing sodium dodecyl sulfate-polyacrylamide gel electrophoresis (SDS-PAGE). Concentrations were determined using an extinction coefficient of $\epsilon=2900 \mathrm{M}^{-1} \mathrm{~cm}^{-1}$ at $274 \mathrm{~nm}$ for the truncated protein and $4250 \mathrm{M}^{-1} \mathrm{~cm}^{-1}$ for wt Hfq (Gill and von Hippel 1989). Ultraviolet spectra showed absorbance ratios of $\mathrm{A}_{275 \mathrm{~nm}} / \mathrm{A}_{255 \mathrm{~nm}}$ (peak to valley) of $\geq 1.8$. Analysis of the spectra indicated $<5 \%$ contaminating nucleic acids (Sun and Wartell 2006).

\section{RNA synthesis and purification}

The following RNAs were purchased commercially (Integrated DNA Technologies) and purified by HPLC: DsrA $A_{\text {DII }}$ (AACGA AUUUUUUAAGUGCUUCUUGCUUAAGCAAGUUUC), OxyS18 (GAAUAACUAAAGCCAACG), and $\mathrm{A}_{18}$. DsrA $\mathrm{A}_{\mathrm{DII}}$ and $\mathrm{A}_{18}$ were also purchased with 6-carboxyfluorescein (FAM) linked to their $5^{\prime}$ end. The full-length DsrA, OxyS, and RprA RNAs were cloned as described previously and transcribed using a T7 MEGAscript High Yield RNA transcription kit (Ambion) (Updegrove et al. 2008). They were ${ }^{32} \mathrm{P}$-labeled at their $5^{\prime}$ end using standard phosphatase and kinase reactions and purified by gel extraction (Sambrook and Russell 2001).

\section{Mass spectrometry and cross-linking of $\mathrm{Hfq}$ to RNA}

Twenty microliter samples were prepared by adding Hfq to fixed amounts of $\mathrm{A}_{18}, \mathrm{DsrA}_{\mathrm{DII}}$, or OxyS-18 in phosphate binding buffer

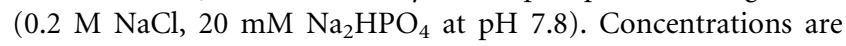
described in Results. For the Hfq- $\mathrm{A}_{18}$ mixture, $10 \mu \mathrm{L}$ of $0.2 \mathrm{M}$ EDC (1-ethyl-3-3-dimethylaminopropyl carbodiimide hydrochloride; Pierce) was added and allowed to react for $4 \mathrm{~h}$ at room temperature. For the other Hfq-RNA mixtures, $2 \mu \mathrm{L}$ of a $3 \%$ formaldehyde solution was added and allowed to react for $15 \mathrm{~min}$ at room temperature. One microliter of $3 \mathrm{M}$ glycine (in water) was then added to quench the reaction (Niranjanakumari et al. 2002). Twenty microliters of the Hfq-RNA solutions described above was then concentrated to $3 \mu \mathrm{L}$ with a C4 ZipTip (Millipore) and then mixed with $3 \mu \mathrm{L}$ of matrix solution. The matrix solution was prepared by adding $20 \mathrm{mg}$ of sinapinic acid and $50 \mathrm{mg}$ ammonium citrate in $500 \mu \mathrm{L}$ of $18 \mathrm{M} \Omega$ deionized water. One microliter of analyte-matrix mixture was then deposited onto a 100-well stainless steel MALDI plate. The MALDI-MS experiments were performed using a Voyager DE STR MALDI-TOF mass spectrometer (Applied Biosystems) equipped with a 337-nm $\mathrm{N}_{2}$ laser $(3 \mathrm{~Hz})$. The accelerating voltage, grid voltage, and delay time were typically $25 \mathrm{kV}, 91 \%$, and $1500 \mathrm{nsec}$, respectively. The laser intensity was checked daily to obtain the best signal-to-noise ratio. Mass spectra were obtained by averaging 10-50 laser shots.

\section{Analytical ultracentrifugation}

\section{Sedimentation velocity}

Sedimentation studies were performed in a Beckman Optima XLA analytical ultracentrifuge equipped with absorbance optics and an An60 Ti rotor at $19.7^{\circ} \mathrm{C}$. Temperature was calibrated as described previously (Liu and Stafford 1995). Velocity data were typically collected at the appropriate speeds using $274 \mathrm{~nm}$ for Hfq and 495 $\mathrm{nm}$ for $\mathrm{FAM}-\mathrm{A}_{18}$ at a spacing of $0.01 \mathrm{~cm}$ with one flash at each point in a continuous-scan mode. When collecting data at multiple wavelengths, care must be taken to collect data at peaks to avoid dramatic signal variations due to wavelength uncertainty $( \pm 4 \mathrm{~nm})$ with the XLA. All experiments were initially analyzed with Sedfit to produce $c(s)$ distributions (Schuck et al. 2002) and with $\mathrm{DCDT}^{+2}$ to produce $g(s)$ distributions and weight average $S$ value (Philo 2006). Direct boundary fitting of velocity data to discrete models can also be performed with the program Sedanal (Stafford and Sherwood 2004). Analysis with Sedanal requires input of molecular weight, extinction coefficients, and density increments (typically estimated from 1 -vbar ${ }^{\star}$ rho values). The buffer solution density was estimated in Sednterp to be $1.01920 \mathrm{gm} / \mathrm{mL}$ at $19.7^{\circ} \mathrm{C}$. The vbar of Hfq was estimated with Sednterp (Laue et al. 1992) to be 0.7248 . The vbar of FAM- $A_{18}$ is assumed to be 0.55 . The extinction coefficient of FAM- $\mathrm{A}_{18}$ at $495 \mathrm{~nm}$ is $75,000 \mathrm{M}^{-1} \mathrm{~cm}^{-1}$ or, using a molecular weight of $6113 \mathrm{Da}, 12.269 \mathrm{~mL} / \mathrm{mg} / \mathrm{cm}$. The extinction coefficient of Hfq at $274 \mathrm{~nm}$ is $0.400 \mathrm{~mL} / \mathrm{mg} / \mathrm{cm}$ (Stafford and Sherwood 2004). Parameter uncertainty is calculated with an Fstat routine within Sedanal at the $95 \%$ confidence interval and reported in $a<$, $>$ format.

\section{Sedimentation equilibrium}

Hfq alone (at 2, 4, and $8 \mu \mathrm{M}$ ) or mixed at a 1:1 ratio with FAM- $\mathrm{A}_{18}$ was spun at $19.7^{\circ} \mathrm{C}$ and at $12 \mathrm{~K}, 16 \mathrm{~K}$, and $20 \mathrm{~K}$ in six-channel double sector cells. Data on $\mathrm{Hfq}$ alone were collected at $274 \mathrm{~nm}$. Data with mixtures of Hfq and FAM-A 18 were collected at $495 \mathrm{~nm}$. Equilibrium at each speed was judged with the software utility WinMATCH (http://www.biotech.uconn.edu/auf/?i=aufftp). This program makes a least-square comparison of successive scans to establish that equilibrium has been achieved. Values for density, vbar, and extinction coefficients were as described under Sedimentation Velocity. Nine data sets from three concentrations and three speeds were best fit to a single species model using Sedanal. Molecular weight uncertainty is calculated with Fstat as described above.

\section{Polyacrylamide gel electrophoresis}

\section{Gel mobility shift assay}

Binding reactions of $\mathrm{Hfq}$ and $\mathrm{FAM}-\mathrm{A}_{18}$ were carried out in the phosphate binding buffer $\left(0.2 \mathrm{M} \mathrm{NaCl}, 20 \mathrm{mM} \mathrm{Na}_{2} \mathrm{HPO}_{4}\right.$ at $\mathrm{pH}$ 7.8). wt Hfq, Hfq-65, or both were added to FAM- $\mathrm{A}_{18}$ and the 
reactions allowed to equilibrate at $25^{\circ} \mathrm{C}$ for $10 \mathrm{~min}$ prior to the addition of $3.2 \mu \mathrm{L}$ of gel loading buffer $(100 \mathrm{mM}$ Tris- $\mathrm{Cl}$ at $\mathrm{pH}$ $6.8,4 \%[\mathrm{w} / \mathrm{v}]$ SDS, $0.2 \%[\mathrm{w} / \mathrm{v}]$ bromophenol blue, $20 \%[\mathrm{v} / \mathrm{v}]$ glycerol). Final reaction volumes were $20 \mu \mathrm{L}$ and contained $0.6 \%$ SDS. The SDS was added in order to enhance the negative charge of the $\mathrm{Hfq} \bullet \mathrm{A}_{18}$ complexes and enable them to migrate into the gel prior to the free $\mathrm{A}_{18}$ running out the bottom. The concentration of $\mathrm{Hfq}$ (moles hexamer) in each reaction varied between 2 and 3 $\mu \mathrm{M}$, and the concentration of FAM- $\mathrm{A}_{18}$ was $1 \mu \mathrm{M}$. The total reaction volumes were electrophoresed into a $6 \%$ polyacrylamide (29:1) gel with $4 \%$ glycerol that was layered onto a $2.5-\mathrm{cm}$ bottom plug consisting of $15 \%$ polyacrylamide (29:1). The latter was employed to slow and retain the free $A_{18}$. The gel was $20 \mathrm{~cm} \times 20$ $\mathrm{cm} \times 1.5 \mathrm{~mm}$. Electrophoresis was conducted at $120 \mathrm{~V}$ at $4^{\circ} \mathrm{C}$ using $1 \times$ TBE buffer for $\sim 8 \mathrm{~h}$. Analysis of the gels used excitation and emission wavelengths of 473 and $520 \mathrm{~nm}$, respectively, of the Fujifilm Image Reader FLA-3000.

Similar competition gel assays were carried out in which wt Hfq, Hfq-65, or both were bound with ${ }^{32} \mathrm{P}$-labeled DsrA, RprA, or OxyS in $15 \mu \mathrm{L}$ binding solution $(50 \mathrm{mM} \mathrm{NaCl}, 50 \mathrm{mM} \mathrm{KCl}, 100$ $\mathrm{mM} \mathrm{NH} \mathrm{NH}_{4} \mathrm{Cl} 20 \mathrm{mM}$ Tris- $\mathrm{HCl}$ at $\mathrm{pH} 8.0,4 \%$ glycerol). The indicated amounts of $\mathrm{Hfq}$ were added to the indicated amount of sRNA and the reaction allowed to equilibrate for $10 \mathrm{~min}$ at $25^{\circ} \mathrm{C}$ prior to running on a $8 \%$ polyacrylamide (29:1) gel with $3 \%$ glycerol. Electrophoresis was conducted at $120 \mathrm{~V}$ at $4^{\circ} \mathrm{C}$ using $1 \times$ TBE buffer for $\sim 2 \mathrm{~h}$. Imaging and analysis of the gels were made using the Fujifilm Image Reader FLA-3000.

\section{Fluorescence anisotropy measurements}

Fluorescence anisotropy measurements of Hfq binding to FAM$\mathrm{A}_{18}$ were carried out at room temperature in the $0.5 \mathrm{M} \mathrm{NaCl}$ and $20 \mathrm{mM}$ Tris ( $\mathrm{pH} \mathrm{8.3)} \mathrm{solvent} \mathrm{as} \mathrm{previously} \mathrm{described} \mathrm{(Sun} \mathrm{and}$ Wartell 2006). The L-format was employed with the excitation monochromator at $490 \mathrm{~nm}$ and emission monochromator at 522 $\mathrm{nm}$. Anisotropy values were obtained from the average of 10 iterations using an integration time of 4-8 sec for each measurement depending on FAM- $\mathrm{A}_{18}$ concentration. The slits employed were set at 1 or $2 \mathrm{~mm}$. wt $\mathrm{Hfq}$ was serially titrated into fluorescence cells with a working volume of $1 \mathrm{~mL}$ or $0.5 \mathrm{~mL}$ for FAM$\mathrm{A}_{18}$ at $2 \mathrm{nM}$. When $5 \mu \mathrm{M}$ of FAM-A $\mathrm{A}_{18}$ was employed, a $50 \mu \mathrm{L}$ micro-cell was employed. The fluorescence intensity of FAM- $\mathrm{A}_{18}$ showed a small decrease with Hfq binding after accounting for dilution $(\sim 2 \%)$. Similar anisotropy experiments were carried using DsrA $_{\text {DII }}$ with FAM attached to its 5 ' end. The solvent employed for the FAM-DsrA $A_{D I I}$ experiments was $0.1 \mathrm{M} \mathrm{NaCl}$ and $20 \mathrm{mM}$ Tris (8.3) since $\mathrm{Hfq}$ affinity for DsrA $\mathrm{A}_{\mathrm{DII}}$ increased with decreasing salt concentration and conditions favoring strong binding were sought (data not shown). Unlike FAM- $\mathrm{A}_{18}$, Hfq binding decreased the

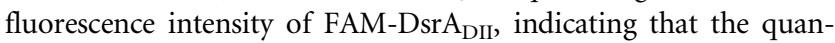
tum yield of the bound fluorophore was less than the free molecule. The ratio of quantum yield for bound versus free FAM-DsrA $A_{D I}$, $\mathrm{Q}_{\mathrm{b}} / \mathrm{Q}_{\mathrm{f}}$, was determined to be 0.70 by saturating FAM-DsrA $\mathrm{AII}_{\mathrm{DI}}$. The change in anisotropy was corrected for this factor (Lundblad et al. 1996).

\section{Analysis of fluorescence anisotropy data}

The two models employed in the analysis of Hfq binding to FAM$\mathrm{A}_{18}$ at low concentration (nM) were described by Sun and Wartell
(2006). Both assume that Hfq exists only as hexamers. The first model assumes a one-to-one complex forms between the $\mathrm{Hfq}$ hexamer and FAM- $\mathrm{A}_{18}$. An equation describing the fluorescence anisotropy in terms of the dissociation constant $\mathrm{K}_{\mathrm{d}}$ and other parameters of the experiment can be derived (Lundblad et al. 1996) and is given by Equation 1.

$$
A=A_{\mathrm{f}}+\left(A_{\mathrm{b}}-A_{\mathrm{f}}\right)\left[\beta-\left(\beta^{2}-4 \mathrm{R}_{\mathrm{t}} \mathrm{P}_{\mathrm{t}}\right)^{1 / 2}\right] / 2 \mathrm{R}_{\mathrm{t}},
$$

where $\beta=\mathrm{R}_{\mathrm{t}}+\mathrm{P}_{\mathrm{t}}+\mathrm{K}_{\mathrm{d}}$. $A$ is the measured anisotropy of FAM- $\mathrm{A}_{18}$ during the titration; $A_{\mathrm{f}}$ and $A_{\mathrm{b}}$ are the anisotropy of the free and bound FAM- $\mathrm{A}_{18}$ respectively; and $\mathrm{R}_{\mathrm{t}}$ and $\mathrm{P}_{\mathrm{t}}$ are the total concentrations of FAM- $\mathrm{A}_{18}$ and Hfq hexamer respectively. Nonlinear least-squares fit of the equation to data was made. For a situation where binding quenches the fluorescence of the RNA (i.e., $D_{\text {srA }}$ DII $)$, Equation 1 has to be corrected for the difference in quantum yields for free and bound RNA $\left(\mathrm{Q}_{\mathrm{f}}, \mathrm{Q}_{\mathrm{b}}\right)$. Defining $\alpha=$ $\left[\beta-\left[\beta^{2}-4 R_{t} P_{t}\right]^{1 / 2}\right] / 2 R_{t}$ one obtains

$$
A=\left[A_{\mathrm{f}}+\left(A_{\mathrm{b}}\left(\mathrm{Q}_{\mathrm{b}} / \mathrm{Q}_{\mathrm{f}}\right)-A_{\mathrm{f}}\right) \alpha\right] /\left[1-\left(1-\left(\mathrm{Q}_{\mathrm{b}} / \mathrm{Q}_{\mathrm{f}}\right)\right) \alpha\right]
$$

The second model assumed that Hfq hexamers bind FAM- $\mathrm{A}_{18}$ in a two-step reaction. The binding reaction is described by a dissociation constant $\mathrm{K}_{1}$ for binding the first $\mathrm{Hfq}$ hexamer, and a dissociation constant $\mathrm{K}_{2}$ for binding a subsequent $\mathrm{Hfq}$ hexamer:

$$
\mathrm{R}+\mathrm{P} \quad \leftrightarrow \quad \mathrm{RP} \text { with } \mathrm{K}_{1}=(\mathrm{R})(\mathrm{P}) / \mathrm{RP}
$$

$$
\mathrm{RP}+\mathrm{P} \quad \leftrightarrow \quad \mathrm{RP}_{2} \text { with } \mathrm{K}_{2}=(\mathrm{RP})(\mathrm{P}) / \mathrm{RP}_{2}
$$

$\mathrm{P}$ corresponds to $\mathrm{Hfq}$ hexamer and $\mathrm{R}$ is FAM- $\mathrm{A}_{18}$. Data were fit to the second model using the BIOEQS program (Royer and Beechem 1992; Royer 1993). This algorithm performs a nonlinear least-squares fit of Equation 3 to the anisotropy data using parameters corresponding to the standard state free energies related to $K_{1}$ and $K_{2}$, anisotropies of free RNA, RNA in the RP complex, and RNA in the $\mathrm{RP}_{2}$ complex. The anisotropy of the free FAM- $A_{18}$ was fixed to the experimental value, and the remaining four parameters fit to the data. Supplementary information for Figures $\mathrm{S} 1$ to $\mathrm{S} 3$ is available upon request.

\section{SUPPLEMENTAL MATERIAL}

Supplemental material is available for this article.

\section{ACKNOWLEDGMENTS}

We were supported by a Georgia Tech/CDC seed grant and funding from the NASA Astrobiology Institute as well as a URS award to C.T. by the Institute of Bioengineering and Biosciences.

Received September 8, 2010; accepted November 24, 2010.

\section{REFERENCES}

Arluison V, Mura C, Guzman MR, Liquier J, Pellegrini O, Gingery M, Regnier P, Marco S. 2006. Three-dimensional structures of fibrillar Sm proteins: Hfq and other Sm-like proteins. J Mol Biol 356: 86-96. 
Arluison V, Hohng S, Roy R, Pellegrini O, Regnier P, Ha T. 2007. Spectroscopic observation of RNA chaperone activities of Hfa in post-transcriptional regulation by a small non-coding RNA. Nucleic Acids Res 35: 999-1006.

Azam TA, Hiraga S, Ishihama A. 2000. Two types of localization of the DNA-binding proteins within the Escherichia coli nucleoid. Genes Cells 5: 613-626.

Bloomfield VA, Crothers DM, Tinoco I. 2000. Nucleic acids: Structures, properties, and functions. University Science Books, Sausalito, CA.

Brennan RG, Link TM. 2007. Hfq structure, function and ligand binding. Curr Opin Microbiol 10: 125-133.

Brescia CC, Mikulecky PJ, Feig AL, Sledjeski DD. 2003. Identification of the Hfq-binding site on DsrA RNA: Hfq binds without altering DsrA secondary structure. RNA 9: 33-43.

Butland G, Peregrin-Alvarez JM, Li J, Yang W, Yang X, Canadien V, Starostine A, Richards D, Beattie B, Krogan N, et al. 2005. Interaction network containing conserved and essential protein complexes in Escherichia coli. Nature 433: 531-537.

Cann JR. 1989. Phenomenological theory of gel electrophoresis of protein-nucleic acid complexes. J Biol Chem 264: 17032-17040.

Carmichael GG, Weber K, Niveleau A, Wahba AJ. 1975. The host factor required for RNA phage Qbeta RNA replication in vitro. Intracellular location, quantitation, and purification by polyadenylate-cellulose chromatography. J Biol Chem 250: 3607-3612.

Cunning C, Brown L, Elliott T. 1998. Promoter substitution and deletion analysis of upstream region required for rpoS translational regulation. J Bacteriol 180: 4564-4570.

de Haseth PL, Uhlenbeck OC. 1980a. Interaction of Escherichia coli host factor protein with oligoriboadenylates. Biochemistry 19: 6138-6146.

de Haseth PL, Uhlenbeck OC. 1980b. Interaction of Escherichia coli host factor protein with Q beta ribonucleic acid. Biochemistry 19: 6146-6151.

Folichon M, Arluison V, Pellegrini O, Huntzinger E, Regnier $\mathrm{P}$, Hajnsdorf E. 2003. The poly(A) binding protein Hfa protects RNA from RNase E and exoribonucleolytic degradation. Nucleic Acids Res 31: 7302-7310.

Folichon M, Allemand F, Regnier P, Hajnsdorf E. 2005. Stimulation of poly(A) synthesis by Escherichia coli poly(A)polymerase I is correlated with Hfq binding to poly(A) tails. FEBS J 272: 454463.

Geissmann TA, Touati D. 2004. Hfq, a new chaperoning role: Binding to messenger RNA determines access for small RNA regulator. EMBO J 23: 396-405.

Gill SC, von Hippel PH. 1989. Calculation of protein extinction coefficients from amino acid sequence data. Anal Biochem 182: 319-326.

Karas M, Gluckmann M, Schafer J. 2000. Ionization in matrix-assisted laser desorption/ionization: Singly charged molecular ions are the lucky survivors. J Mass Spectrom 35: 1-12.

Kawamoto H, Koide Y, Morita T, Aiba H. 2006. Base-pairing requirement for RNA silencing by a bacterial small RNA and acceleration of duplex formation by Hfq. Mol Microbiol 61: 10131022.

Kleinschmidt C, Tovar K, Hillen W. 1991. Computer simulations and experimental studies of gel mobility patterns for weak and strong non-cooperative protein binding to two targets on the same DNA: Application to binding of tet repressor variants to multiple and single tet operator sites. Nucleic Acids Res 19: 1021-1028.

Lakowicz JR. 2006. Principles of fluorescence spectroscopy. Springer, New York.

Laue TM, Shah B.D., Ridgeway, T.M. and Pelletier, S.L. 1992. Analytical ultracentrifugation in biochemistry and polymer sciences. (ed. SE Harding, et al.) Royal Society of Chemistry, Cambridge, UK.

Le Derout J, Folichon M, Briani F, Deho G, Regnier P, Hajnsdorf E. 2003. Hfq affects the length and the frequency of short oligo(A) tails at the 3' end of Escherichia coli rpsO mRNAs. Nucleic Acids Res 31: 4017-4023.
Le Derout J, Boni IV, Regnier P, Hajnsdorf E. 2010. Hfq affects mRNA levels independently of degradation. BMC Mol Biol 11: 17.

Lease RA, Woodson SA. 2004. Cycling of the Sm-like protein Hfq on the DsrA small regulatory RNA. J Mol Biol 344: 1211-1223.

Lenz DH, Mok KC, Lilley BN, Kulkarni RV, Wingreen NS, Bassler BL. 2004. The small RNA chaperone Hfq and multiple small RNAs control quorum sensing in Vibrio harveyi and Vibrio cholerae. Cell 118: 69-82.

Link TM, Valentin-Hansen P, Brennan RG. 2009. Structure of Escherichia coli Hfq bound to polyriboadenylate RNA. Proc Natl Acad Sci 106: 19292-19297.

Liu S, Stafford WF III. 1995. An optical thermometer for direct measurement of cell temperature in the Beckman instruments XLA analytical ultracentrifuge. Anal Biochem 224: 199-202.

Lundblad JR, Laurance M, Goodman RH. 1996. Fluorescence polarization analysis of protein-DNA and protein-protein interactions. Mol Endocrinol 10: 607-612.

Majdalani N, Hernandez D, Gottesman S. 2002. Regulation and mode of action of the second small RNA activator of RpoS translation, RprA. Mol Microbiol 46: 813-826.

Majdalani N, Vanderpool CK, Gottesman S. 2005. Bacterial small RNA regulators. Crit Rev Biochem Mol Biol 40: 93-113.

Masse E, Escorcia FE, Gottesman S. 2003. Coupled degradation of a small regulatory RNA and its mRNA targets in Escherichia coli. Genes Dev 17: 2374-2383.

Mikulecky PJ, Kaw MK, Brescia CC, Takach JJ, Sledjeski D, Feig AL. 2004. Escherichia coli $\mathrm{Hfq}$ has distinct interaction surfaces for DsrA, rpoS and poly(A) RNAs. Nat Struct Mol Biol 11: 1206-1214.

Mohanty BK, Kushner SR. 2006. The majority of Escherichia coli mRNAs undergo post-transcriptional modification in exponentially growing cells. Nucleic Acids Res 34: 5695-5704.

Mohanty BK, Maples VF, Kushner SR. 2004. The Sm-like protein Hfq regulates polyadenylation dependent mRNA decay in Escherichia coli. Mol Microbiol 54: 905-920.

Moller T, Franch T, Hojrup P, Keene DR, Bachinger HP, Brennan RG, Valentin-Hansen P. 2002a. Hfq: A bacterial Sm-like protein that mediates RNA-RNA interaction. Mol Cell 9: 23-30.

Moller T, Franch T, Udesen C, Gerdes K, Valentin-Hansen P. 2002b. Spot 42 RNA mediates discoordinate expression of the E. coli galactose operon. Genes Dev 16: 1696-1706.

Morita T, Maki K, Aiba H. 2005. RNase E-based ribonucleoprotein complexes: Mechanical basis of mRNA destabilization mediated by bacterial noncoding RNAs. Genes Dev 19: 2176-2186.

Niranjanakumari S, Lasda E, Brazas R, Garcia-Blanco MA. 2002. Reversible cross-linking combined with immunoprecipitation to study RNA-protein interactions in vivo. Methods 26: 182-190.

Philo JS. 2006. Improved methods for fitting sedimentation coefficient distributions derived by time-derivative techniques. Anal Biochem 354: 238-246.

Royer CA. 1993. Improvements in the numerical analysis of thermodynamic data from biomolecular complexes. Anal Biochem 210: 91-97.

Royer CA, Beechem JM. 1992. Numerical analysis of binding data: Advantages, practical aspects, and implications. Methods Enzymol 210: 481-505.

Salim NN, Feig AL. 2010. An upstream Hfq binding site in the fhlA mRNA leader region facilitates the OxyS-fhlA interaction. PLoS ONE 5: e13029. doi: 10.1371/journal.pone.0013028.

Sambrook J, Russell DW. 2001. Molecular cloning: A laboratory manual. Cold Spring Harbor Laboratory Press, Cold Spring Harbor, NY.

Schuck P, Perugini MA, Gonzales NR, Howlett GJ, Schubert D. 2002. Size-distribution analysis of proteins by analytical ultracentrifugation: Strategies and application to model systems. Biophys $J$ 82: 1096-1111.

Schumacher MA, Pearson RF, Moller T, Valentin-Hansen P, Brennan RG. 2002. Structures of the pleiotropic translational regulator $\mathrm{Hfq}$ and an Hfq-RNA complex: A bacterial Sm-like protein. EMBO J 21: 3546-3556. 


\section{Updegrove et al.}

Serdyuk IN, Zaccai NR, Zaccai G. 2007. Methods in molecular biophysics: Structure, dynamics, function. Cambridge University Press, Cambridge.

Sledjeski DD, Whitman C, Zhang A. 2001. Hfq is necessary for regulation by the untranslated RNA DsrA. J Bacteriol 183: 1997-2005.

Soper TJ, Woodson SA. 2008. The rpoS mRNA leader recruits Hfq to facilitate annealing with DsrA sRNA. RNA 14: 1907-1917.

Stafford WF, Sherwood PJ. 2004. Analysis of heterologous interacting systems by sedimentation velocity: Curve fitting algorithms for estimation of sedimentation coefficients, equilibrium and kinetic constants. Biophys Chem 108: 231-243.

Steege DA. 2000. Emerging features of mRNA decay in bacteria. RNA 6: $1079-1090$.

Sun X, Wartell RM. 2006. Escherichia coli Hfq binds A18 and DsrA domain II with similar 2:1 Hfq6/RNA stoichiometry using different surface sites. Biochemistry 45: 4875-4887.

Takada A, Wachi M, Kaidow A, Takamura M, Nagai K. 1997. DNA binding properties of the hfa gene product of Escherichia coli. Biochem Biophys Res Commun 236: 576-579.

Tsui HC, Feng G, Winkler ME. 1997. Negative regulation of mutS and mutH repair gene expression by the $\mathrm{Hfq}$ and $\mathrm{RpoS}$ global regulators of Escherichia coli K-12. J Bacteriol 179: 7476-7487.
Updegrove T, Wilf N, Sun X, Wartell RM. 2008. Effect of Hfq on RprA-rpoS mRNA pairing: Hfq-RNA binding and the influence of the 5' rpoS mRNA leader region. Biochemistry 47: 11184-11195.

Updegrove TB, Correia JJ, Galletto R, Bujalowski W, Wartell RM. 2010. E. coli DNA associated with isolated Hfq interacts with Hfq's distal surface and C-terminal domain. Biochim Biophys Acta 1799: $588-596$.

Valentin-Hansen P, Eriksen M, Udesen C. 2004. The bacterial Sm-like protein Hfq: a key player in RNA transactions. Mol Microbiol 51: 1525-1533.

Vecerek B, Rajkowitsch L, Sonnleitner E, Schroeder R, Blasi U. 2008. The C-terminal domain of Escherichia coli $\mathrm{Hfq}$ is required for regulation. Nucleic Acids Res 36: 133-143.

Vytvytska O, Jakobsen JS, Balcunaite G, Andersen JS, Baccarini M, von Gabain A. 1998. Host factor I, Hfq, binds to Escherichia coli ompA mRNA in a growth rate-dependent fashion and regulates its stability. Proc Natl Acad Sci 95: 14118-14123.

Waters LS, Storz G. 2009. Regulatory RNAs in bacteria. Cell 136: 615628 .

Zhang A, Wassarman KM, Ortega J, Steven AC, Storz G. 2002. The Sm-like Hfa protein increases OxyS RNA interaction with target mRNAs. Mol Cell 9: 11-22. 

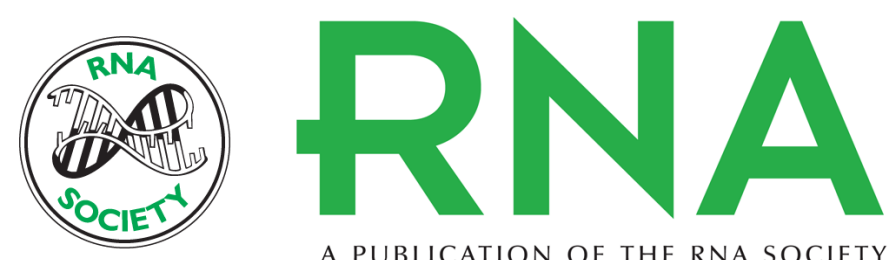

A PUBLICATION OF THE RNA SOCIETY

\section{The stoichiometry of the Escherichia coli Hfq protein bound to RNA}

Taylor B. Updegrove, John J. Correia, Yanfeng Chen, et al.

RNA 2011 17: 489-500 originally published online January 4, 2011

Access the most recent version at doi:10.1261/rna.2452111

Supplemental

Material

References

\section{License}

Email Alerting

Service
http://rnajournal.cshlp.org/content/suppl/2010/12/21/rna.2452111.DC1

This article cites 55 articles, 15 of which can be accessed free at: http://rnajournal.cshlp.org/content/17/3/489.full.html\#ref-list-1

\section{top right corner of the article or click here.}

Receive free email alerts when new articles cite this article - sign up in the box at the

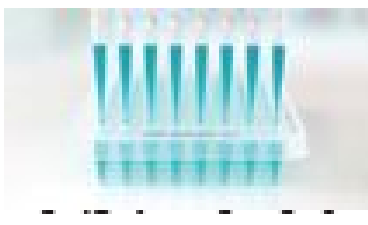

